DOI: $10.20472 / E F C .2018 .009 .002$

\title{
RYTA DZIEMIANOWICZ
}

University of Bialystok, Faculty of Economics and Management, Poland

ANETA KARGOL-WASILUK

University of Bialystok, Faculty of Economics and Management, Poland

ANNA WILDOWICZ-GIEGIEL

University of Bialystok, Faculty of Economics and Management, Poland

\section{NEW FISCAL POLICY? LESSON FROM THE CRISIS}

\begin{abstract}
:
The article aims to rethinking the role of fiscal policy in the process of macroeconomic stabilization which over 30 years has been strongly negated by neoliberal doctrine. The study is based on the analysis of premises for expansionary fiscal policy implementation both from theoretical and empirical perspective. In the face of strong economic shocks, such as the recent crisis, the special attention is paid on its size, instruments and time horizon. The content analysis of the literature supported by empirical evidence devoted to fiscal policy in context of its impact on the course of business cycles was conducted. The authors used Ameco and IMF data referring to the public finance with special focus on countries belonging to euro area and the US. It was claimed that the attempts to reduce increasing public debt via fiscal consolidation in early years of the crisis 2009-2011 have very likely resulted in a higher debt to GDP as euro area entered its second recession. At the same time, only countries with large fiscal space like the US could afford the bigger fiscal stimulus, and as a result registered output losses in these economies were smaller compared to Europe. In conclusion it should be emphasized that contractionary fiscal policy in a depressed economy had not only a negative short-term impact on GDP, but through hysteresis effects permanently affected the expected path of future growth. Despite this, the costs of expansionary fiscal policy are also worth to be taken into account and even in a depressed economy such policy surely should be timely, targeted and contemporary as sustainability of public finance in the long-term is recommended.
\end{abstract}

\section{Keywords:}

fiscal policy, austerity, fiscal consolidation, hysteresis

JEL Classification: E62, E63 


\section{INTRODUCTION: A COURSE CORECCTION}

The relationship between fiscal policy and economic growth has long been fascinating economists. The effectiveness of fiscal policy in combating economic crisis was the subject of continuous dispute between Keynesians and Monetarists. The article concerns the role of fiscal policy in economy after the crisis in years 2008-2009 with the focus on fiscal stimulus implemented by many advanced economies like the US and the EU countries, including the euro area. The special attention is paid on the effectiveness of fiscal instruments used in a depressed economy. The literature review of Keynesian and Neoliberal approach towards fiscal policy and their main recommendations addressed to policymakers in times of severe crisis, supplemented by empirical evidence, may contribute to find the answer to the following questions: What instruments of fiscal policy are desirable in the fight against economic slowdown, especially in the case of deepened depression? Whether expansionary fiscal policy can be effective in achieving both macroeconomic stabilization and fiscal balance in the long-term? What should be the future shape of fiscal policy? The authors inspired by research conducted by DeLong and Summers (2012) and Fatas and Summers (2016) formulated the hypothesis that there is an urgent need for the re-examining fiscal policy as fiscal consolidation aimed at debt reduction instead of expansionary fiscal policy in a depressed economy with short-term nominal interest rates at the zero bound does not always bring both macroeconomic and fiscal stabilization. Krugman (2015) noticed that "(...) fiscal austerity (...), when the neutral rate is unattainable, is a terrible idea, even if you have high public debt. Why? Because multipliers are large, so that austerity has a large cost in lost output and unemployment; given hysteresis, it may even make the long-run fiscal situation worse. The appropriate policy during the era of the binding zero lower bound is fiscal stimulus to achieve full employment, and worry about debt later." Contrary to the previous literature, fiscal prudence in times of crisis seems to be questionable. There is a consensus among economists representing different schools of thought that idea of austerity may have no solid foundations, and furthermore, many empirical research has confirmed the critics.

The aim of this research is to rethinking the role of fiscal policy in the process of macroeconomic stabilization which over 30 years has been strongly negated by neoliberal doctrine along with the rationale for implementation of expansionary fiscal policy. In the face of strong economic shocks the question on size, instruments and time horizon with regards to fiscal policy seems of high importance. To achieve the research aim, content analysis of the literature devoted to fiscal policy was done in context of its influence on real output was done, among others, on the basis of Eurostat and IMF data referring to the public finance with special focus on countries belonging to euro area and the US. 


\section{KEYNESIAN VS. NEOLIBERAL APPROACH TO FISCAL POLICY}

The revolution in economic thinking begun after the Great Depression of the 1930s thanks to British economists John Maynard Keynes and his famous work "The General Theory of Employment, Interest and Money" published in 1936. Keynes contested the crucial for classical economics faith in free market that possesses self-balancing mechanism leading to full-employment. Under the conditions of free market and perfect competition, the price mechanism solves economic problems in the most efficient way and there is no place for fiscal and monetary policies aimed at macroeconomic stabilization. However, according to the Keynesian macroeconomic system, the economy would not automatically come to the full employment equilibrium due to the lack of effective demand or deflationary gap. Taking into account that "in the long run, we are all dead" the government intervention, instead of waiting for market forces to fix things over the long term, is recommended. Keynes simultaneously set three fundamental assumptions. First, rigid prices prevent certain markets from achieving equilibrium in the short-term. Secondly, demand, particularly consumption expenditure, is determined by disposable income and the way households react to changes in income depends on their marginal propensity to consume (MPC) and other non-income factors including people's expectations about changes in prices and their incomes, cost and availability of consumer credit or total wealth of households. Thirdly, savinginvestment determinants, such as profit expectations and interest rates, are responsible for the lack of equilibrium between private sector investment and saving. Deficient aggregate demand could lead to prolonged periods of recession and high unemployment. To reduce the damage of economic slowdown, state intervention through appropriate countercyclical fiscal and monetary policies is necessary to moderate the recession.

Following Keynes, fiscal policy plays a crucial role in economic growth stabilization, while monetary policy occupies a secondary place. Generally, countercyclical fiscal policies should act against the direction of business cycle. It means that in the case of recession, the main goal of fiscal policy is to raise production and reduce unemployment. In time of recession the increase in government spending or tax cuts are especially desired as they have a positive impact on the aggregate consumption spending, consequently raising aggregate demand, real income and employment level (Birol, Gencer, 2014). In addition, it is worth to emphasize that under the conditions of depressed economy the changes in real output are strengthened by multiplier effect as any increase in aggregate demand results in even bigger increase in national income. Expansionary fiscal policy runs to budget deficit and national debt which are not a negative phenomenon as far as the rate of unemployment is high and saving outweighs investment. Such policy can also be supported by monetary policy which aims to reduce interest rates encouraging to investment. However, in the light of Keynesian view point fiscal policy seems to be more effective in this scope and contributes to economic stabilization, even though budget deficit financed by domestic borrowings increases as a result of its implementation. The reverse fiscal policy based on decrease in 
government spending and increase in tax rates is implemented when the economy is overheated and the threat of inflation occurs. Keynesian economics dominated economic theories and was successfully used in economic policy of many post-war countries of Western Europe and in the US until the 1970s. Next under the influence of oil crisis both high inflation and high unemployment appeared in the majority of advanced economies. In response to the inadequacy of Keynes prescriptions in explanation of supply-side shocks and processes of stagflation that took place in the economy of the 70s and 80s of XX century, the Monetarists' approach gained prominence. The foundation of Monetarism is the quantity theory of money which embraces several key tenets such as (Jahan, Mahmud, Papageorgiou, 2014):

- $\quad$ short-term monetary non-neutrality - an increase in the money stock temporary affects real output and employment in the short term as wages and prices take time to adjust,

- $\quad$ long-term monetary neutrality - an increase in the money stock would be followed by an increase in the general price level in the long term, with no effects on real consumption, investment and output,

- $\quad$ constant money growth rule - the money supply should grow at a fixed rate adjusted to the growth rate of real GDP, leaving the price level unchanged.

One of the main representatives of Monetarism was Nobel Prize-winning economist Milton Friedman (1912-2006). According to Monetarists, the economy is inherently stable and potential fluctuations are primarily attributed to destabilizing variations in the money supply caused by the monetary authorities. Otherwise, Monetarists believe that "only money matters" assigning monetary policy a key role due to its impact on fluctuations in nominal and real income and prices. The source of all recessions and depressions stems from severe contraction of money and credit, while booms and inflations by excessive increases in the money supply (Alavinasab, 2016). In contrast to Keynesians, Monetarists held that fiscal policy is not effective policy tool due to the crowding-out effect of private expenditures. Moreover, economic agents anticipate the increase of the future taxes to cover the budget deficits generating by public spending and in the light of the Ricardian equivalence the increase of public spending financed by loans, or by taxes, does not contribute to the welfare state improvement as the consumption and GDP remain unchanged (Marinas, 2010). Besides, the state of government budget determines the level of taxes and has a considerable effect on interest rates. Friedman claimed that if the federal government runs a large deficit that means the government has to borrow in the market, which raises the demand for loanable funds and so tends to raise interests rates (Friedman, Heller, 1969, p. 50). Expansionary fiscal policy financed by government borrowing pushes up interest rates what negatively affects private investment. The appearance of crowding-out effects, related to substitution of private for public investment and consumption expenditures, confirms that fiscal policy is not effective. In addition, monetarists state that the lags 
caused by legislative procedure, are argument against discretionary fiscal policy implementation. However, the lags in the application of discretionary monetary policy also happen, and as a result Central Bank actions will intensify the business cycles rather than moderate them. To sum up, Monetarist doctrine is based on the assumption that the economy is inherently stable and has a natural tendency to move along a trend path of output determined by the growth of productivity factors. The government activity on the market should be reduced to minimum. There is no active role for stabilization policy. The attempts to mitigate demand shocks through countercyclical fiscal policy are ineffective, while in this respect monetary policy is only a supportive tool compared to the economy's ability to self-regulation. In the opposition to Keynesians, they argue that budget deficits will have only a moderate impact on aggregate demand unless they are accompanied by the change in money supply.

\section{EXPANSIONARY FISCAL POLICY AS A RESPONSE TO GLOBAL CRISIS}

After the bankruptcy announcement of Lehman Brothers in mid-September 2008, turmoil in the financial markets, which began in August 2007, quickly turned into a serious financial crisis. Problems in the financial system also quickly embraced the real economy. This has led to the worst economic downturn in the world since 1980. The European Union, including the euro area, has also not been spared from the crisis. Economic activity in many countries has fallen sharply. Already in 2007, a decline in real economic growth of 0.2 pp was recorded in 14 European Union countries. In 2008 and 2009 , the average GDP dynamics in the EU was $+0.5 \%$ and $-4.4 \%$ respectively, and its accumulated decline was 7.5 pp (Ziółkowska, 2016, p. 5). OECD governments have responded quickly to these events, taking action both in monetary and fiscal policy. Their main goal was to counteract the negative impact of the financial crisis on the real economy. The role of fiscal policy in limiting the economic slowdown, for the first time was no less important, and perhaps even more important than monetary policy. Monetary policy, which impact was limited by low interest rates, did not bring the expected results without fiscal stimuli (Szymańska, 2014, p. 332). 


\section{Figure 1. Types of fiscal costs from financial crises}

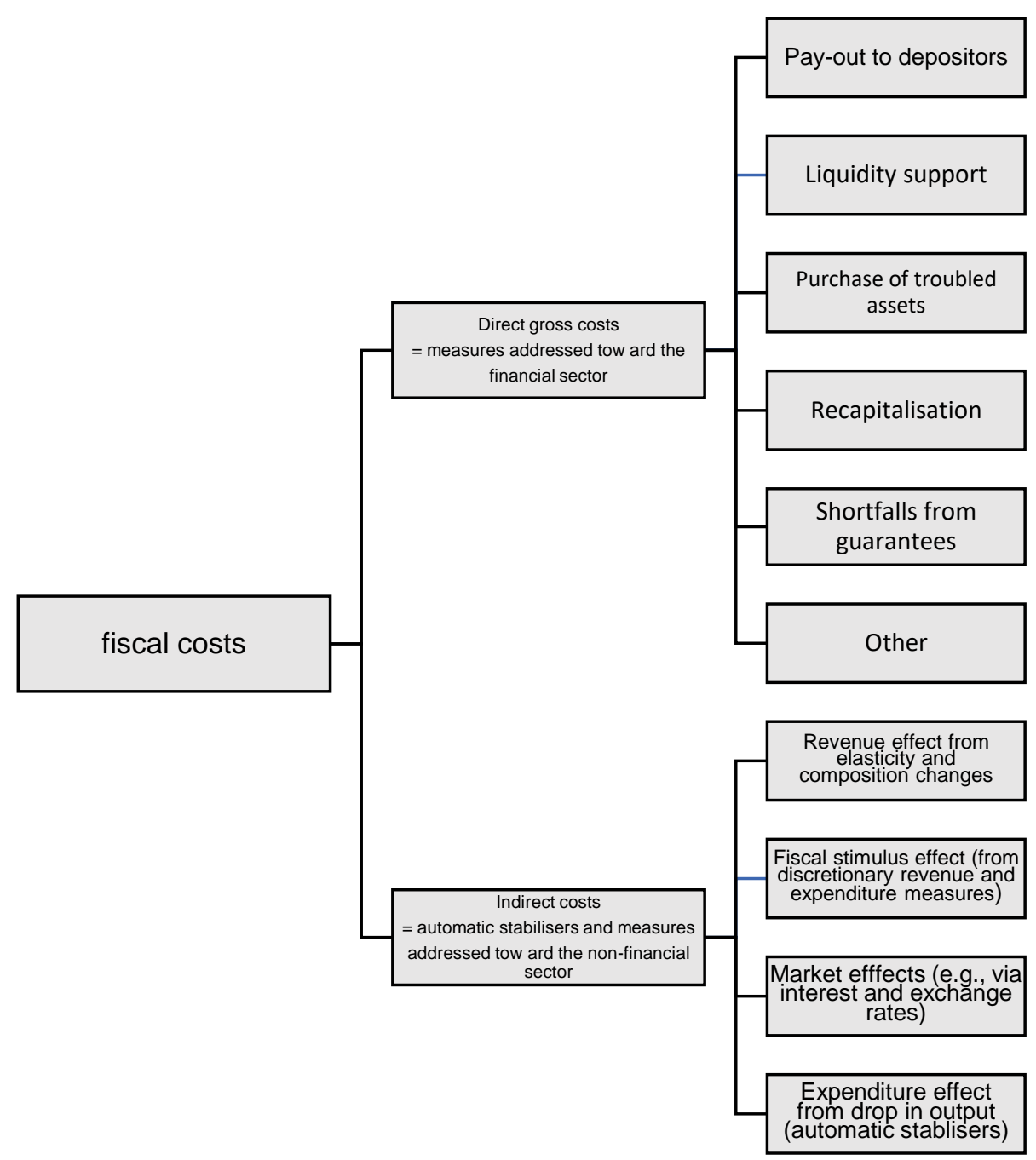

Source: Public Finances, 2009, p. 114.

In the first phase of the recession, fiscal policy was clearly expansive. The activities were conducted in two ways. Firstly, the banking sector was mainly supported by public direct expenditure, simultaneously ensuring the stability of the financial system. At the same time, the governments of OECD countries to mitigate the effects of the global economic slowdown, apart from the use of automatic stabilizers, additionally used discretionary fiscal policy, reduced tax rates, introduced tax reliefs addressed both to enterprises (e.g. the possibility of accelerating depreciation) and households, increased spending on unemployed people. Their main task was to stimulate demand (Spilimbergo et al. 2008, p. 2). The packages of fiscal stimuli, both direct and indirect, used as part of the expansionary fiscal policy in 2008-2009 are presented in Figure 1.

The role of automatic stabilizers in limiting the negative effects of the crisis was additionally strengthened. It is estimated, for example, that in Germany in 2009 and in 2010 automatic stabilizers had a fiscal effect of around 2.5\% of GDP (A review, 2011, p. 9). Moreover, it should be emphasized that the applied fiscal stimulus packages had 
one more goal. "(...) Besides the expected economic effects, they were to convince the public about the government's determination to fight the crisis. Such a propaganda effect is not offered by monetary policy, which is much less transparent to the public" (Lubiński, 2010, p. 6).

Table 1. Summary of selected stimulus packages in response to the financial crisis

\begin{tabular}{|c|c|c|c|}
\hline & \multicolumn{3}{|c|}{ Stimulus packages } \\
\hline USA & $\begin{array}{l}\text { The Economic Stimulus } \\
\text { Act of } 2008 \text { - February } \\
\mathbf{2 0 0 8} \\
\text { Amount: USD } 152 \text { billion } \\
\text { (1.06\% of } 2008 \text { GDP) } \\
\text { Distribution: USD } 120 \\
\text { billion in lump sum payments } \\
\text { to US taxpayers. USD } 32 \\
\text { billion distributed between } \\
\text { tax cuts for businesses and } \\
\text { payments to veterans and } \\
\text { pensioners }\end{array}$ & $\begin{array}{l}\text { American Recovery and } \\
\text { Reinvestment Act of } 2009 \\
\text { - February } 2009 \\
\text { Amount: USD } 787 \text { billion } \\
\text { (5.57\% of } 2009 \text { GDP) } \\
\text { Distribution: USD } 288 \text { billion } \\
\text { in tax cuts and subsidies, USD } \\
275 \text { billion for public } \\
\text { investments, USD } \\
224 \text { billion for health, } \\
\text { education and social security } \\
\text { payments }\end{array}$ & $\begin{array}{l}\text { Extra stimulus package for } \\
\text { infrastructure } \\
2010 \\
\text { Amount: USD } 50 \text { billion } \\
\text { (0.34\% of forecast } 2010 \text { GDP) } \\
\text { Distribution: All for } \\
\text { infrastructure }\end{array}$ \\
\hline $\begin{array}{l}\text { EU } \\
\text { centrally }\end{array}$ & \multicolumn{3}{|c|}{$\begin{array}{l}2008 \text { European Union stimulus plan } \\
\text { Amount: EUR } 200 \text { billion (1.8\% of EU } 2008 \text { GDP) } \\
\text { Distribution: Contributions to the member states to enable them to: increase unemployment } \\
\text { benefits and their duration, as well as support for households; reduce VAT and social security } \\
\text { contributions for low-income households; provide loan and credit guarantees for companies. }\end{array}$} \\
\hline Germany & $\begin{array}{l}\text { Konjunkturpakete } \\
\text { (economic stimulus } \\
\text { packages) I- } 2008 \\
\text { Amount: EUR } 32 \text { billion } \\
\text { (1.3\% of } 2008 \text { GDP) } \\
\text { Distribution: Public } \\
\text { investment }\end{array}$ & $\begin{array}{l}\text { Konjunkturpakete } \\
\text { (economic stimulus } \\
\text { packages) II- } 2009 \\
\text { Amount: EUR } 50 \text { billion } \\
\text { (2\% of } 2009 \text { GDP) } \\
\text { Distribution: Public } \\
\text { investment and tax cuts }\end{array}$ & \\
\hline $\begin{array}{l}\text { UK } \\
\text { Sweden } \\
\text { Norway }\end{array}$ & $\begin{array}{l}\text { UK } \\
\text { Stimulus packages 2008- } \\
\mathbf{2 0 0 9} \\
\text { Amount: GBP } 31 \text { billion } \\
\text { (2.2\% of } 2009 \text { GDP) } \\
\text { Distribution: GDP } 20 \text { billion } \\
\text { to VAT, GBP } 1 \text { billion in } \\
\text { support for the construction } \\
\text { sector, GBP } 10 \text { billion for the } \\
\text { construction of schools, } \\
\text { hospitals and green energy. } \\
\text { The objective was to create } \\
100000 \text { job }\end{array}$ & $\begin{array}{l}\text { Sweden } \\
\text { Stimulus packages } 2009 \\
\mathbf{2 0 1 0} \\
\text { Amount 2009: SEK } 45 \text { billion } \\
\text { (1.45\% of } 2009 \text { GDP) } \\
\text { Amount 2010: SEK } 60 \text { billion } \\
\text { (2\% of forecast } 2010 \text { GDP) } \\
\text { Distribution: Primarily support } \\
\text { for counties and municipalities, } \\
\text { plus increased funds for } \\
\text { labour-market programmes. }\end{array}$ & $\begin{array}{l}\text { Norway } \\
\text { Stimulus package January } \\
\mathbf{2 0 0 9} \\
\text { Amount: NOK } 20 \text { billion } \\
\text { (0.84\% of } 2009 \text { GDP) } \\
\text { (1.08\% of } 2009 \text { mainland GDP) } \\
\text { Distribution: NOK } 16.6 \text { billion } \\
\text { for increased public } \\
\text { expenditure, NOK } 3.3 \text { billion in } \\
\text { tax cuts. The increases in } \\
\text { expenditure primarily related to } \\
\text { the purchase of goods and } \\
\text { services from the private sector, } \\
\text { particularly from the } \\
\text { construction industry, while } \\
\text { NOK } 6.4 \text { billion transferred to } \\
\text { municipalities }\end{array}$ \\
\hline
\end{tabular}

Source: Larsson, 2011, p. 26.

The scale and nature of fiscal intervention varied in particular OECD countries (Table 1). Public spending was primarily increased in the US, while indirect instruments of fiscal policy, mainly taxes, were used to a greater extent in the EU Member States which governments are forced to respect the criteria by the Maastricht Treaty. 
According to OECD forecasts the size of these fiscal packages measured by cumulated deviations of fiscal balances over the period 2008-10 amounted to about 3.5\% of GDP, and the level of support from the stimulus to GDP both in 2009 and 2010 was around $0.5 \%$ for the average OECD country. However, considerable cross-country variation in the size of packages and their impact on output were observed. In case of the US and Australia fiscal expansion provided a stimulus that clearly exceeded $1 \%$ of GDP in both 2009 and 2010. For other countries the likely impact of the fiscal packages was more modest judged against the magnitude of the output gap (OECD Economic Outlook, 2009 , p. 22). In the next years, the process of public finance consolidation was initiated.

Table 2. G-20 Countries: Impact of Fiscal Expansion on Growth a/

\begin{tabular}{|l|l|l|l|l|l|}
\hline & 2008 & 2009 & 2010 & Average \\
\hline Fiscal expansion & \multicolumn{5}{|c|}{ (in percent of GDP) } \\
\hline Discretionary impulse & 0.5 & 1.2 & -0.5 & 0.4 \\
\hline Total fiscal expansion: & 1.8 & 2.4 & 0.4 & 0.5 \\
Expenditures & 1.1 & 1.4 & 0.6 & 1.0 \\
Revenue & 0.7 & 1.0 & -0.2 & 0.5 \\
\hline Cumulative discretionary impulse & 0,5 & 1.8 & 1.3 & 1.2 \\
\hline Cumulative fiscal expansion & 1.8 & 4.2 & 4.5 & 3.5 \\
\hline Impact on growth (low-high range) & $\mathbf{b} /$ & (in percent) \\
\hline Total fiscal expansion & $0.6-2.4$ & $0.8-3.2$ & $0.1-0.9$ & $0.5-2.2$ \\
\hline
\end{tabular}

a/ Fiscal expansion and growth are calculated with respect to the previous year, except for cumulative

discretionary stimulus and cumulative fiscal expansion, which is calculated with respect to 2007.

b/ The range of growth estimates reflects different assumptions on fiscal multipliers. The low set of multipliers included a multiplier of 0.3 on revenue, 0.5 on capital spending and 0.3 on other spending. The high set of multipliers included a multiplier of 0.6 on revenue, 1 , on capital spending and 1 for other spending. For calculation of the growth impact of total fiscal expansion a weighted average of current and capital expenditure multipliers was used.

c/ For the calculations of growth impacts from fiscal expansion, the change of the overall balance was adjusted: for Russia and Saudi Arabia, the change in non-oil revenues was used (rather than total revenues); for Saudi Arabia, the change in discretionary measures were used (rather than total expenditures); for the U.S., estimates of losses from financial sector support were excluded.

Source: (IMF, 2009, p. 32).

Regardless of the controversy in the literature, it can be stated that the fiscal expansion applied in 2008-2009 has clearly contributed to the shortening of the economic slowdown. In this case, however, the structure of the fiscal package is significant on which the short-term and long-term effects depend. Empirical research shows that in a short time consumption which always stimulates demand is more effective than investment. Therefore, reduction of consumption taxes rather than income taxes or direct public expenditure may contribute to shortening the recession. In the long-term, however, public investment supports growth acceleration, while consumption does not exert such significant effects (Baldacci, Gupta, Mulas-Granados, 2009). The problem is 
finding the answer to the questions: What does it mean "short and long horizon" in various economies? How long should the fiscal stimulation of the economy last? When should the fiscal consolidation begin? Undoubtedly, „the policy challenge is a trade-off between the benefits of starting to address the debt problem earlier versus risking damage to a still-fragile economy by engaging in contractionary fiscal policy, or failure to continue with expansionary fiscal policy" (Gravelle, Hungerford, 2011, p.1).

\section{PRESSURE ON FISCAL CONSOLIDATION. THE MYTH OF AUSTERITY}

Expansionary fiscal policy was used by the majority of European countries, including euro area and the US, to support aggregate demand, employment and economic growth in times of global crisis of 2008. Its implementation unfortunately contributed to the increase in budget deficits and debts. The lack of fiscal stability, especially in the Southern Euro Area, simultaneously forced the need for fiscal consolidation. In the face of economic recession, the policymakers searched for the trade off between traditional Keynesian and Neoliberal approach to fiscal policy.

The austerity is defined as a set off budgetary cuts that would restore market confidence. As Alesina and al. (2014) claimed "The deficit reduction policies followed by several OECD countries in 2009-2013 were motivated, especially in the European Union, by bond market reaction to large debts and deficits". Fiscal consolidation rather supports than undermines long-run economic growth. This statement has been commonly forced by neoliberal economists and political parties for the past few decades. They were absolutely against state intervention and perceived deficit and debt only as a result of irresponsible fiscal policy regardless of the reasons behind it. The focus on fiscal consolidation and its growth enhancing effects became the question discussed by many economists who found both theoretical and empirical confirmation of such approach. Supporters of fiscal consolidation mainly resisted on non-Keynesian effects of fiscal policy. There are two potential channels for so-called 'expansionary effects' of austerity (Kleis, Moessinger, 2016). On the demand side, sustained and significant reduction of government expenditures may lead consumers to believe that tax reduction will occur in the future, and as a result consumers' expectations regarding the increase in permanent income will positively affect private consumption. Therefore, if fiscal adjustments are perceived as permanent and successful, they contribute to the decrease in real interest rates of government bonds because austerity diminishes the risk premium associated with public debt issuance (Afonso, 2006). The attempt to reduce the public sector borrowing requirements through fiscal consolidation also benefits investors as real market interest rates decrease and the crowding in of private investment takes place. Expansionary effects of fiscal consolidation may additionally appear on the supply side but the final effects are ambiguous and they depend on the composition of fiscal adjustments. Regardless of this observation, there is a possibility that a decrease in government employment may induce trade unions to demand lower 
wage increases which can foster firms' profits and private investment (Alesina and Ardagna, 2010).

It has to be underlined that two studies by well-respected economists Alesina and Ardagna (2010) and Reinhart and Rogoff (2010) laid the theoretical basis for austerity. The first mentioned authors, Alesina and Ardagna (2010) examined fiscal adjustments using a panel data of 21 OECD countries from 1970 to 2007 . On the basis of empirical data they managed to find evidence of improved economic performance in economies which undertook substantial fiscal consolidation. Next Reinhart and Rogoff (2010) based on the obtained results concluded that whereas the link between growth and debt seems relatively weak at 'normal' debt levels, median growth rates for countries with public debt over $90 \%$ of GDP are about $1 \%$ lower than otherwise, while average growth rates are several percent lower. What is more, this tendency concerns both advanced economies and emerging markets.

However, the recent several studies has confirmed that austerity is not only ineffective at improving disequilibrium of public finance, but surprisingly it can be self-defeating in certain circumstances (Holland and Portes, 2012; De Long and Summers, 2012, Blanchard and Leigh, 2013, Fatas and Summers, 2016). The pressure on fiscal consolidation, particularly too soon and harsh austerity is a wrong remedy in times of crisis. It could hurt economies in recession, as well as does not bring the desirable effect of public debt reduction and even makes the situation worse (Melloni 2018).

\section{WHY THE RESULTS OF AUSTERITY POLICY IN THE POST-CRISIS ECONOMIES ARE QUESTIONABLE?}

To answer to this question it is worth to pay attention on the situation of economies deepening into recession along with the sudden increase in their public debt. In case of countries such as Greece, Spain, Portugal or Italy there was a course correction - from fiscal stimulus to austerity - distinctively observed in years 2009-2011 in order to reestablish the credibility of their debtors. The austerity via budgetary cuts and structural reforms aimed at increasing competitiveness was recommended by many institutions e.g. International Monetary Fund and European Commission in times of recent crisis. It was simultaneously considered that the deeper the crisis, the harsher the programme of austerity should be implemented, otherwise countries at fault have to pay the consequences of their irresponsible fiscal actions what is meant: no more support from any European institutions or even expulsion from the Eurozone.

Unfortunately, the empirical results of implemented post-crisis policies in euro area indicate that fiscal prudence neither contributes to macroeconomic stabilization, nor diminishes public debt. Moreover, the undertaken attempts to reduce public debt via fiscal consolidation in early years of the crisis 2009-2011 have very likely resulted in a 
higher debt to GDP as euro area entered its second recession. Austerity in depressed economies had then not only a negative short-run impact on GDP but permanently affected the expected path of future growth. The effects of fiscal consolidation turned out to be completely opposite to those intended. The austerity deepened the macroeconomic imbalances within the Eurozone.

\section{Table 3. Fiscal developments in the euro area (percentages of GDP)}

\begin{tabular}{|l|l|r|r|r|r|r|r|r|r|r|r|r|r|}
\hline & & 2007 & 2008 & 2009 & 2010 & 2011 & 2012 & 2013 & 2014 & 2015 & 2016 & 2017 & 2018 \\
\hline $\mathrm{a}$ & total revenue & 44.7 & 44.4 & 44.4 & 44.3 & 44.9 & 46.1 & 46.7 & 46.7 & 46.2 & 46.1 & 46.1 & 45.9 \\
\hline $\mathrm{b}$ & total expenditure & 45.3 & 46.6 & 50.7 & 50.5 & 49.2 & 49.7 & 49.8 & 49.2 & 48.3 & 47.6 & 47.2 & 46.8 \\
\hline $\begin{array}{l}\text { of } \\
\text { which }\end{array}$ & & & & & & & & & & & & \\
\hline $\mathrm{c}$ & $\begin{array}{l}\text { Interest } \\
\text { expenditure }\end{array}$ & 2.9 & 2.9 & 2.8 & 2.7 & 3 & 3 & 2.8 & 2.6 & 2.4 & 2.2 & 2 & 1.9 \\
\hline $\mathrm{d}$ (b-c) & $\begin{array}{l}\text { Primary } \\
\text { expenditure }\end{array}$ & 42.4 & 43.7 & 47.9 & 47.8 & 46.2 & 46.7 & 47 & 46.6 & 45.9 & 45.4 & 45.2 & 44.9 \\
\hline a-b & Budget balance & -0.6 & -2.2 & -6.3 & -6.2 & -4.3 & -3.6 & -3.1 & -2.5 & -2.1 & -1.5 & -1.1 & -0.9 \\
\hline a-d & $\begin{array}{l}\text { Primary budget } \\
\text { balance }\end{array}$ & 2.3 & 0.7 & -3.5 & -3.5 & -1.3 & -0.6 & -0.3 & 0.1 & 0.3 & 0.7 & 0.9 & 1 \\
\hline & $\begin{array}{l}\text { Cyclically } \\
\text { Adjusted Budget } \\
\text { Balance }\end{array}$ & -2.4 & -3.3 & -4.4 & -4.9 & -3.4 & -1.9 & -0.8 & -0.7 & -0.6 & -0.5 & -0.7 & -0.9 \\
\hline & Gross debt & 64.9 & 68.6 & 78.4 & 84.1 & 86.8 & 91.4 & 93.7 & 94.2 & 92.1 & 91.1 & 89.3 & 87.2 \\
\hline & $\begin{array}{l}\text { Memo item: real } \\
\text { GDP (percentage } \\
\text { changes) }\end{array}$ & & & & & & & & & & & & \\
\hline
\end{tabular}

Source: Ameco database, http://ec.europa.eu/economy_finance/ameco/user/serie/SelectSerie.cfm;

OECD Fiscal Balance and Public Indebtedness (CABB i Pdebt);ECB Monthly Bulletin. December 2009, p. 85; ECB Monthly Bulletin, December 2012, p. 77; ECB Monthly Bulletin, December 2013, p. 85; ECB, Monthly Bulletin, December 2014, p. 76; ECB Statistics Bulletin, https://sdw.ecb.europa.eu/reports.do?node $=1000004045$

The consequence of the shock caused by the global financial crisis of 2007-2009 was a sharp deterioration of the state of public finances in the countries belonging to the Eurozone. The situation began to deteriorate from 2008-2009, which is evidenced by the increase of deficit and public debt. In 2008, the deterioration in the euro area budget balance was partly due to decline in the average annual real GDP growth rate (from 3 $\%$ in 2007 to $0.4 \%$ in 2008). In particular, the economic slowdown had a negative impact on the revenue-to-GDP ratio due to the smaller tax base. Part of the revenue reduction was related to asset prices in many countries. The expenditure ratio increased due to the mainly cyclical expansion of social benefits and transfers. In addition to the impact of deterioration of the macroeconomic situation, the deficit ratio increased due to tax cuts in many euro area countries. The higher cyclically adjusted budget deficit thus reflected such discretionary policy, as well as the impact of disappearing revenue windfalls. The deterioration in the total budget balance in the euro area masks significant divergences across countries (ECB 2008). The fiscal situation sharply deteriorated in 
Ireland, Greece, Spain and Malta, the deficit ratio rose up accordingly to $7.0 \%, 10.2 \%$, $4.4 \%, 4.2 \%$ (Table 4).

\section{Table 4. Budget balance}

\begin{tabular}{|c|c|c|c|c|c|c|c|c|c|c|}
\hline GEO/TIME & 2007 & 2008 & 2009 & 2010 & 2011 & 2012 & 2013 & 2014 & 2015 & 2016 \\
\hline European Union (25) & -0.8 & -2.5 & -6.6 & -6.4 & -4.5 & -4.3 & -3.3 & -3.0 & -2.4 & -1.7 \\
\hline Belgium & 0.1 & -1.1 & -5.4 & -4.0 & -4.1 & -4.2 & -3.1 & -3.1 & -2.5 & -2.5 \\
\hline Bulgaria & 1.1 & 1.6 & -4.1 & -3.1 & -2.0 & -0.3 & -0.4 & -5.5 & -1.6 & 0.0 \\
\hline Czech Republic & -0.7 & -2.0 & -5.5 & -4.2 & -2.7 & -3.9 & -1.2 & -1.9 & -0.6 & 0.7 \\
\hline Denmark & 5.0 & 3.2 & -2.8 & -2.7 & -2.1 & -3.5 & -1.2 & 1.1 & -1.8 & -0.6 \\
\hline Germany & 0.2 & -0.2 & -3.2 & -4.2 & -1.0 & 0.0 & -0.1 & 0.3 & 0.6 & 0.8 \\
\hline Estonia & 2.7 & -2.7 & -2.2 & 0.2 & 1.2 & -0.3 & -0.2 & 0.7 & 0.1 & -0.3 \\
\hline Ireland & 0.3 & -7.0 & -13.8 & -32.1 & -12.7 & -8.0 & -6.1 & -3.6 & -1.9 & -0.7 \\
\hline Greece & -6.7 & -10.2 & -15.1 & -11.2 & -10.3 & -8.9 & -13.2 & -3.6 & -5.7 & 0.5 \\
\hline Spain & 1.9 & -4.4 & -11.0 & -9.4 & -9.6 & -10.5 & -7.0 & -6.0 & -5.3 & -4.5 \\
\hline France & -2.5 & -3.2 & -7.2 & -6.8 & -5.1 & -4.8 & -4.1 & -3.9 & -3.6 & -3.4 \\
\hline Croatia & -2.4 & -2.8 & -6.0 & -6.5 & -7.8 & -5.2 & -5.3 & -5.1 & -3.3 & -0.9 \\
\hline Italy & -1.5 & -2.7 & -5.3 & -4.2 & -3.7 & -2.9 & -2.9 & -3.0 & -2.6 & -2.5 \\
\hline Cyprus & 3.2 & 0.9 & -5.4 & -4.7 & -5.7 & -5.6 & -5.1 & -8.8 & -1.2 & 0.5 \\
\hline Latvia & -0.5 & -4.2 & -9.1 & -8.7 & -4.3 & -1.2 & -1.0 & -1.2 & -1.2 & 0.0 \\
\hline Lithuania & -0.8 & -3.1 & -9.1 & -6.9 & -8.9 & -3.1 & -2.6 & -0.6 & -0.2 & 0.3 \\
\hline Luxembourg & 4.2 & 3.3 & -0.7 & -0.7 & 0.5 & 0.3 & 1.0 & 1.3 & 1.4 & 1.6 \\
\hline Hungary & -5.0 & -3.7 & -4.5 & -4.5 & -5.4 & -2.4 & -2.6 & -2.7 & -2.0 & -1.9 \\
\hline Malta & -2.1 & -4.2 & -3.2 & -2.4 & -2.4 & -3.5 & -2.4 & -1.8 & -1.1 & 1.1 \\
\hline Netherlands & 0.2 & 0.2 & -5.4 & -5.0 & -4.3 & -3.9 & -2.4 & -2.3 & -2.1 & 0.4 \\
\hline Austria & -1.4 & -1.5 & -5.3 & -4.4 & -2.6 & -2.2 & -2.0 & -2.7 & -1.0 & -1.6 \\
\hline Poland & -1.9 & -3.6 & -7.3 & -7.3 & -4.8 & -3.7 & -4.1 & -3.6 & -2.6 & -2.5 \\
\hline Portugal & -3.0 & -3.8 & -9.8 & -11.2 & -7.4 & -5.7 & -4.8 & -7.2 & -4.4 & -2.0 \\
\hline Romania & -2.8 & -5.5 & -9.5 & -6.9 & -5.4 & -3.7 & -2.1 & -1.4 & -0.8 & -3.0 \\
\hline Slovenia & -0.1 & -1.4 & -5.8 & -5.6 & -6.7 & -4.0 & -14.7 & -5.3 & -2.9 & -1.9 \\
\hline Slovakia & -1.9 & -2.4 & -7.8 & -7.5 & -4.3 & -4.3 & -2.7 & -2.7 & -2.7 & -2.2 \\
\hline Finland & 5.1 & 4.2 & -2.5 & -2.6 & -1.0 & -2.2 & -2.6 & -3.2 & -2.7 & -1.7 \\
\hline Sweden & 3.4 & 1.9 & -0.7 & 0.0 & -0.2 & -1.0 & -1.4 & -1.6 & 0.2 & 1.1 \\
\hline United Kingdom & -2.6 & -5.2 & -10.1 & -9.4 & -7.5 & -8.2 & -5.4 & -5.5 & -4.3 & -2.9 \\
\hline
\end{tabular}

Source: Eurostat, http://appsso.eurostat.ec.europa.eu/nui/show.do?dataset=gov_10dd_edpt1\&lang=en.

Retrieved on 28.03.2018.

A further drastic deterioration in budgetary balances occurred in 2009. The average general government deficit in the euro area rose from $2.2 \%$ of GDP in 2008 to $6.3 \%$ of GDP in 2009, which means the worst deterioration of the budget since the inception of Economic and Monetary Union. Huge deficits and very large deterioration of the budget compared to the previous year were occurred in almost all countries. In the context of declining economic activity, the increasing deficits and government interventions in response to the financial crisis influenced a fast growing debt-to-GDP ratio (ECB 2009). 
The general government gross debt ratio of the euro area sharply increased from $68.6 \%$ of GDP in 2008 to $78.4 \%$ of GDP in 2009 (Figure 2). There was a simultaneous deterioration in the euro area budget balance and average annual real GDP growth (Table 3).

Figure 2. Government debt as a percentage of GDP in the EU-25 and Euro area 19

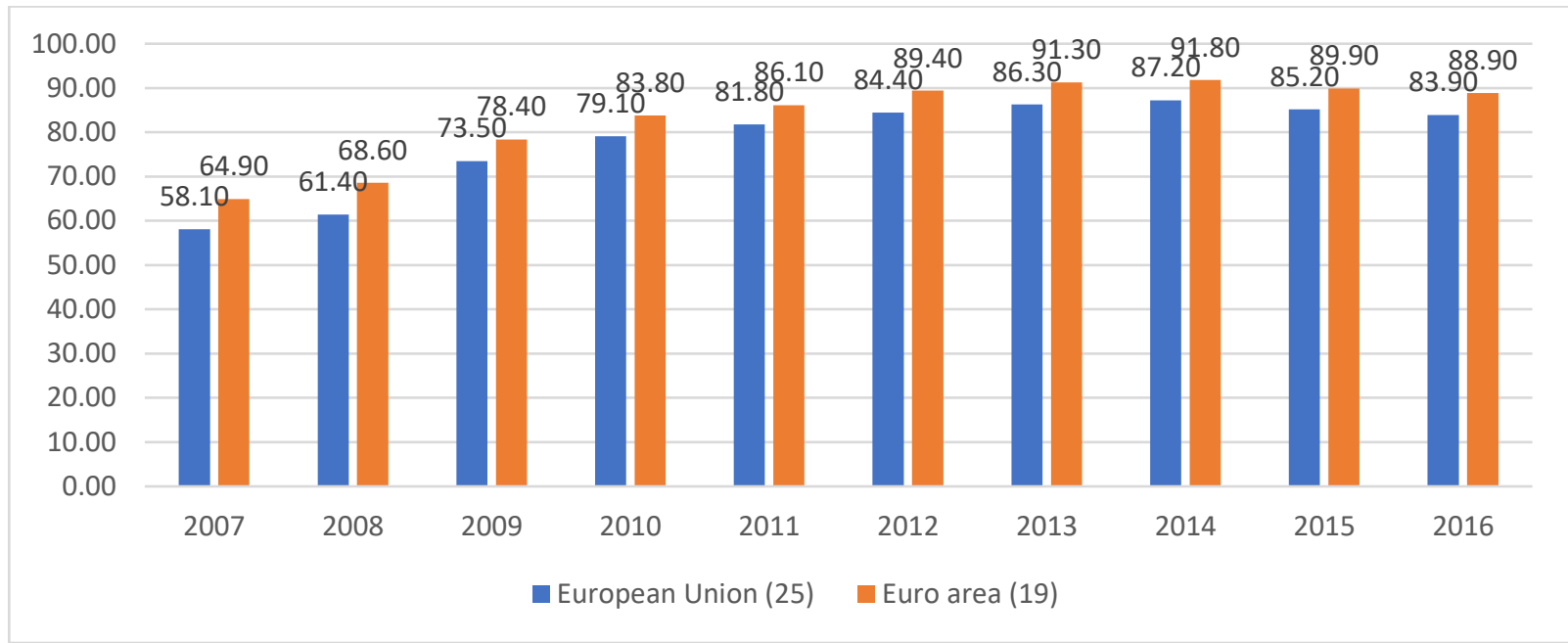

Source: Eurostat, http://appsso.eurostat.ec.europa.eu/nui/show.do?dataset=gov_10dd_edpt1\&lang=en. Retrieved on 28.03.2018.

The stabilization of the average deficit ratio in euro area in 2010 coincided with the economic recovery. On the expenditure side, the slowdown in nominal expenditure can be explained by the withdrawal of fiscal stimulus measures implemented since the end of 2008 and new fiscal consolidation measures balancing the still relatively strong structural growth in social payments, capital transfers and interest payments. The reduction in expenditures was particularly visible in government investment and wages of government employees, as well as in the reduction of employment, as well as wage freezes and even wage cuts in several countries (ECB 2010). In terms of the ratio to GDP, both total government revenue and total government expenditure were broadly unchanged since 2009 , at $44.4 \%$ of GDP and $50.7 \%$ of GDP respectively (Table 3 ). In the next years, tax revenues have increased by $1.5-2 \mathrm{pp}$, while expenditures decreased almost by $3 \mathrm{pp}$. In spite of this, average public debt, for the euro area remains at a higher level than the debt for all member states. Moreover, the economic growth rate has not reached the level of 2007 so far. For the euro area countries it was $2 \%$ compared to $3 \%$ in 2007.

In 2015 Fatas and Summers, on the basis of estimates, suggested that the fiscal consolidation in the European countries caused the reduction of output not only in the short term but also in the medium term and possibly on a permanent basis. It means, 
that it is more difficult to reach the goal of the fiscal consolidation because of the increasing ratio of debt to GDP and reduction of tax revenues.

As austerity programmes brought more costs than benefits, the economists started contesting the sense of fiscal consolidation in times of crisis. Many of them are convinced that the occurrence of deep recession along with short-term nominal interest rates at their zero lower bound, ample cyclical unemployment, and excess capacity requires rather the implementation of expansionary fiscal policy. There are at least two arguments for expansionary fiscal policy in a depressed economy. Firstly, it seems that the constraints imposed by the zero bound limit monetary authority intervention. In such a case, Central Bank is either unable or unwilling to provide additional stimulus through quantitative easing or other means. As monetary policy cannot perform its stabilization role this increases the significance of complementary policy actions, giving rise to the need for credible fiscal policy. Secondly, in the context of severe economic downturn fiscal policy has a major role to play as additional government spending with larger than in normal times fiscal multiplier brings positive effects. The Keynesian fiscal multiplier causes that under the influence of government spending, a greater change in the output level of economy takes place. It is worth to notice that expansionary fiscal policy is more appropriate in recession as both diminishes output losses (weakens hysteresis effects) and increases potential future output. According to Keynes, if economy is under employment level, the sensitivity of investment to interest rates would be low and their potential increase as a result of expansionary fiscal policy, i.e. an increase in government spending, is rather minimal. What is more, when the output gap is large and interests rates are close to the zero bound, expansionary fiscal policy can be selffinancing, and it does not increase future debt burden. Contrary to the Neoliberal view, the government has the power to support demand through fiscal stimulus, mainly increasing spending, and then reverse it without any impact on the risk premium that it pays on its borrowing.

\section{HYSTERESIS EFFECTS OF FISCAL POLICY}

The concept of hysteresis in economics - derived from natural sciences - originally refers to the labour market. Phelps (1972) was the first who noted that "the natural unemployment rate at any future date will depend upon the course of history in the interim. Such a property is sometimes called hysteresis". The phenomenon of hysteresis was further elaborated by Blanchard and Summers (1986) who have noticed that cyclical unemployment turned into structural one. It seems that economic cycles interrupt temporarily the long-term growth dynamics in the same way. According to Blanchard, Cerutti and Summers (2015) recession caused by demand shocks tends to be very persistent. For this reason strong countercyclical fiscal policy is particularly required during a deep cyclical downturn to mitigate hysteresis effects. Fatas and Summers (2016) analysed the permanent effects of fiscal policy shocks, among others 
on the basis of euro area in years 2010-2011. The authors' results provide support for the presence of strong hysteresis effects of fiscal policy on potential output growth both in short-term and long-term. This again sheds a new light on the role of expansionary fiscal policy in combating recession that has been much underestimated by the Neoliberal economists.

More than ten years after the crisis started the current level of output as well as estimates of potential GDP are still much lower than expected. What is worse, it is supposed that many countries that undertook fiscal consolidation too early during the second phase of large recession will not regain their pre-trend crisis level (Fatas and Summers, 2016). On this basis it can be stated that the implemented fiscal policy was completely ineffective. How can it be explained? On the theoretical ground, fiscal multiplier should be regarded which in a depressed economy is substantially greater than in normal times, contributing to the permanent scars on economic output. Its value depends on the state of the economy as the Keynesian theory predicts. Many empirical research indicates that under the conditions of recession fiscal multiplier reaches a value of 2.3, while in expansion is close to zero for most horizons (Auerbach and Gorodnichenko, 2012, Qazizada and Stockhammer, 2015). It is in line with the study of DeLong and Summers (2012) that also noticed that this multiplier may be further magnified by an additional zero-bound effect: the impact of economic expansion on expected inflation and hence on real interest rates. The above citied authors simultaneously paid attention to the fact that austerity in case of economy in liquidity trap when the nominal interest is equal to zero and monetary policy is ineffective may harm economic output. Effect of fiscal consolidation in liquidity trap presents figure 3 . It seems to be evident that due to hysteresis effects, the bigger focus on fiscal consolidation, the longer it takes for the economy to converge towards steady state with no slack in demand, stable prices and, what is crucial, positive nominal interest rates. 
Figure 3: Effects of fiscal consolidation in liquidity trap

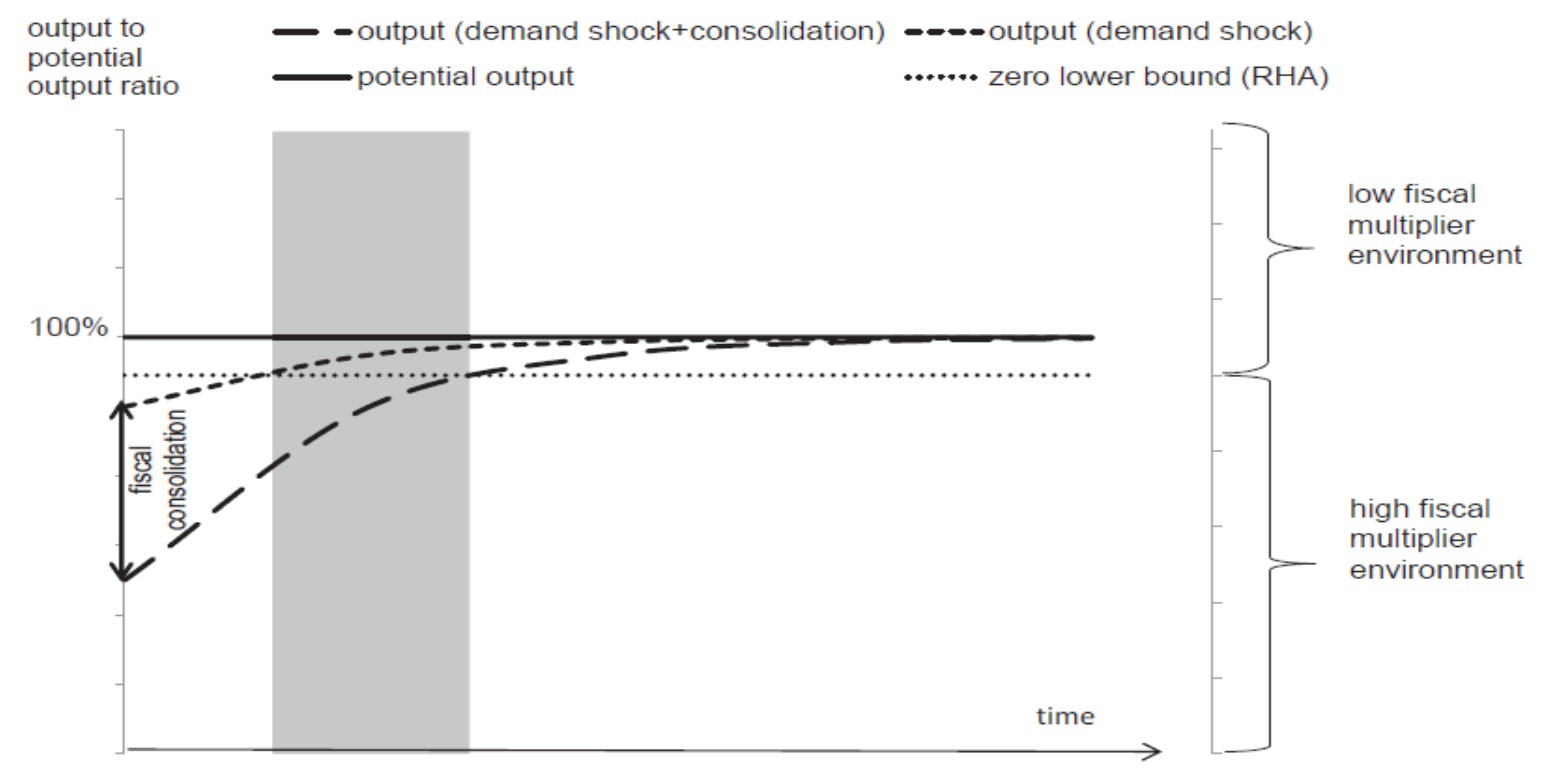

Source: Bukowski 2015.

Fiscal austerity effects in economy in liquidity trap below potential output caused by demand shock and characterized by high fiscal multiplier environment is self-defeating. Not only it negatively affects the output in the current period adequately to the spending cut, but also increases the length of high-multiplier period. Fiscal austerity means lower consumption and investment spending, increasing the number of unemployed. These changes are permanent. As a result of hysteresis, economy loses possible output both in current and future periods. DeLong and Summers (2012) additionally claimed that policies of austerity may well be counterproductive, and furthermore in a depressed economy can erode the long-term fiscal balance. Fiscal prudence may run to higher debt-to-GDP because of their negative impact on potential GDP.

\section{REMARKS ON THE FUTURE OF FISCAL POLICY}

Before the recent financial crisis, monetary policy aimed at achieving the inflation target was perceived as the most important instrument of macroeconomic management, while fiscal policy played a secondary role. However, after the financial crisis and the subsequent crisis in the euro area, more attention was paid to fiscal policy. In the past, a limited understanding of the effects of fiscal policy, disregard of monetary-fiscal interactions, non-effective institutional structures or ignorance of market expectations have often led to bad policies ('́udovít Ódor, Rethinking Fiscal Policy 2017).

Taking into consideration the importance of fiscal policy in stabilizing the economy, the identification of errors in the 'old view' fiscal policy used since the Great Economic Crisis of the thirties of the $X X$ century is required. It is worth emphasizing, that as a result of 
the experience of the last global financial crisis 2007-2009 many economists have been convinced, that 'old view' of fiscal policy is ineffective.

J. Furman stated that the new approach to fiscal policy should appreciate efficiency and effectiveness of expansionary fiscal policy in the situation of low interest rates, low growth and strong international relationships. As he noted, in the past four principles of fiscal policy have dominated (Furman, 2016):

1. A discretionary fiscal policy is dominated by monetary policy as a stabilization tool due to delays in applying, impact and removal of discretionary fiscal stimulus.

2. Even if policymakers get the timing right, discretionary fiscal stimulus would be somewhere between completely ineffective (the Ricardian view) or somewhat ineffective with bad side effects (higher interest rates and crowding-out of private investment).

3. Moreover, fiscal stabilization needs to be undertaken with trepidation, if at all, because the biggest fiscal policy priority should be the long-run fiscal balance.

4. Policymakers foolish enough to ignore (1) through (3) should at least make sure that any fiscal stimulus is very short-run, including pulling demand forward, to support the economy before monetary policy stimulus fully kicks in while minimizing harmful side effects and long-run fiscal harm.

Nowadays, after the long-term dominance of liberal approach we are the witnesses of large changes of the fiscal policy principles and the return to Keynesian policy is observed. First of all, fiscal policy is complementary to monetary policy, and moreover is effective as a countercyclical policy. A discretionary fiscal stimulus can restrain private investment to such an extent that it leads to higher interest rates, which may be beneficial in given circumstances. As a result, a larger fiscal space is created. The author of the above-discussed principles emphasizes large benefits from fiscal policy coordination across countries (Furman 2016).

Considering the comments made by Furman, it is worth stressing that one of the main tasks of fiscal policy in the future is to reduce deficits and debts to a sustainable level, while taking into account the possibility of achieving the potential rate of economic growth in the long-term. The process of fiscal adjustment is not an easy task. The reduction of cyclically adjusted primary budget balance that will be needed to bring debt ratios back to their pre-crisis levels within the next two decades is very large and amounts to several percent of GDP - although there are significant differences across countries. In conclusion, there is no doubt that, although the economic recovery occurred, countries are still facing increasingly complex and diverse challenges. This certainly concerns fiscal policy (Lipsky 2011). 
We have to remember, that "fiscal policy is much politicized because it has very obvious and large redistributive consequences, both within a generation and across generations" (Alesina, Giavazzi 2013). However, there are many unknowns regarding fiscal policy. Undoubtedly, if its stabilizing dimension is taken into account, it is necessary to design an appropriate institutional framework for fiscal policy. The fiscal governance concept, which assumes coordination of fiscal policy using fiscal rules, fiscal councils and medium-term budgetary frameworks, seems to face such a need. Reassuming, coordination of fiscal policy, both at the national and supranational level, for example in the EU, should serve to achieve two main goals (Alińska 2016):

- $\quad$ reduction of consequences of the global financial crisis to such an extent as to achieve the long-term sustainability of public finance,

- $\quad$ minimalization of the additional risks associated with the occurrence of new, unknown and costly financial crises, especially those related directly or indirectly to the public finance sector.

\section{Conclusion}

The implementation of fiscal policy as a stabilizing tool in the context of its effects in combating economic crises after 2007 has provoked an interesting discussion among many economists and policymakers representing different schools and opinions. A distinct return from contractionary to expansionary fiscal policy has been observed and the belief of market fundamentalists that Keynesian policy is ineffective was rejected. As short-term nominal rates hit the zero in 2008, the conventional open-market operations could not be used by Central Bank for macroeconomic stabilization. Under such circumstances it turned out that in a time of deep recession the instruments of discretionary fiscal policy both direct public spending on consumption and indirect through tax system seemed to be more appropriate in the fight against the crisis.

On the basis of available data it can be stressed that the majority of advanced countries followed Keynesian prescriptions and introduced stimulus fiscal packages to mitigate the consequences of economic downturn in years 2008-2009. However, the problem of increasing public debt in many countries, including euro area, accompanied by the contraction in GDP growth rate, caused that most governments faced a dilemma between a policy of fiscal stimulus or fiscal consolidation. The strong pressure from financial markets on fiscal austerity, especially in Southern European Union countries, pushed them into the process of fiscal consolidation. The implemented austerity packages were necessary to provide the sustainability to the public finances but did not bring a positive effects, and what is more even amplified the macroeconomic as well as fiscal imbalances. The results of many empirical research suggest that this phenomenon can be explained by the presence of strong hysteresis effects of fiscal 
policy and their long-term negative impact on economic growth which simultaneously leads to the higher debt to GDP.

To sum up, the conducted analysis showed that the premature fiscal austerity, too harsh and too deep, in time of recent crisis along with the spillover effects of coordinated fiscal consolidation implemented in almost all EU countries contributed to the too slow recovery. Expansionary fiscal policy was only continued by countries with large fiscal space like US and Australia, and as a result the registered output losses in these economies were smaller than in Europe. The observed tendency is in line with the latest empirical research which concerns fiscal consolidation in a depressed economy and hysteresis effects of fiscal policy that may depress future potential output. Regardless of this fact, the costs of expansionary fiscal policy are always worth to be taken into account and even in a depressed economy such policy surely should not be implemented without limit. Undoubtedly, fiscal consolidation is necessary in the longterm. This raises the need for improvements of institutions responsible for fiscal policy, including its shape and consistency. Assuming the certain limitations of fiscal policy, it seems that its instruments should be more rethinking and context-dependent, in other words, timely, targeted and temporary.

\section{References}

A review of global fiscal stimulus (2011). EC-IILS Joint Discussion Paper Series No. 5, http://www.ilo.org/wcmsp5/groups/public/---dgreports/-

inst/documents/publication/wcms_194175.pdf, Retrieved on 04.04.2018.

AFONSO, A. (2006) Expansionary Fiscal Consolidations in Europe. New Evidence. Working Papers. 2006, Series, No. 675, European Central Bank.

ALAVINASAB, S.M. (2016) Monetary Policy and Economic Growth. A Case Study of Iran. International Journal of Economics, Commerce and Management. 2016, Vol. IV, Issue 3, p.234-244.

ALESINA, A.; ARDAGNA, S. (2010) Large Changes in Fiscal Policy: Tax versus Spending. National Bureau of Economic Research. 2010, Vol. 24, 35-68.

ALESINA, A.; BARBIERO, O.; FAVERO, C.; GIAVAZZI, F. and PARADISI, M. (2014) Austerity in 20092013. Economic Policy Journal, 2014.

ALESINA, A.; GIAVAZZI, F. (2013) Fiscal Policy after the Financial Crisis. NBER, 2013.

ALIŃSKA A. (2106). Antykryzysowa polityka fiskalna - cele, uwarunkowania i instrumenty, Annales Universitatis Mariae Curie-Skłodowska. 2016, Vol. L, 1, Sectio H, DOI:10.17951/h.2016.50.1.113, p.113-121.

AUERBACH, A.J.; GORODNICHENKO, Y. (2011) Fiscal Multipliers in Recession and Expansion. NBER Working Papers. 2011, No. 17447. 
BALDACCI E.; GUPTA S. and MULAS-GRANADOS C. (2009) How Effective is Fiscal Policy Response in Systemic Banking Crises?, IMF Working Paper Fiscal Affairs Department. 2009, No. 160.

BIROL, Ö. H.; GENCER, A.H. (2014) The Keynesian System: Fiscal and Monetary Policy Guidelines. GSTF International Journal of Business Review. 2014, Vol. 3, No. 3, p. 106- 119.

BLANCHARD, O.J.; SUMMERS, L.H. (1986) Hysteresis And The European Unemployment Problem. NBER Macroeconomics Annual. 1986, Vol. 1.

BLANCHARD, O.J.; CERUTTI, E. and SUMMERS, L.H. (2015) Inflation and Activity: Two Explorations and Their Monetary Policy Implications. Working Paper Series. 2015, No. WP15-19, Peterson Institute for International Economics.

BUKOWSKI, H. (2015) Fiscal Consolidation As A Self-Fulfilling Prophecy on Fiscal Multipliers. NBP Working Paper. 2015, No. 217.

DELONG, J.B.; SUMMERS, L.H. (2012) Fiscal Policy in a Depressed Economy. Brookings Papers on Economic Activity. Spring 2012, p. 233-265.

ECB (December 2008). Fiscal developments, "Monthly Bulletin".

ECB (December 2009). Fiscal developments, "Monthly Bulletin”.

ECB (December 2010). Fiscal developments, "Monthly Bulletin".

Eurostat, http://appsso.eurostat.ec.europa.eu/nui/show.do?dataset=gov_10dd_edpt1\&lang=en. Retrieved on 28.03.2018.

FATAS, A.; SUMMERS, L.H. (2016) The Permanent Effects of Fiscal Consolidation. NBER Working Paper. 2016, No. 22374, p. 1-34.

FRIEDMAN, M.; HELLER, W.W (1968). Monetary vs. Fiscal Policy. A Dialogue. New York: W.W. Norton\&Company Inc, 1968.

FURMAN, J. (2016), The New View of Fiscal Policy and Its application", remarks to the Conference "Global Implications of Europe's Redesign". New York, OECD, 2016.

GRAVELLE J.G.; HUNGERFORD T.L. (2011) Can contractionary fiscal policy be expansionary?" CRS Report for Congress. Washington: Congressional Research Service. 2011.

HOLLAND, D.; PORTES, J. (2012) Self-Defeating Austerity?. National Institute Economic Review. 2012, No. 222, p.4-10.

IMF (2009), Global Economic Policies and Prospects, Group of Twenty, Meeting of the Ministers and Central Bank Governors, March 13-14, London, U.K., https://www.imf.org/external/np/g20/pdf/031909a.pdf. Retrieved on 04.04.2018.

JAHAN, S.; MAHMUD, A.S. and PAPAGEORGIOU, Ch.(2014) What is Keynesian Economics. Finance \& Development, September 2014, p.53. 
KEYNES., J.M. (1936) The General Theory of Employment, Interest and Money". London: Palgrave Macmillan 2007, Reprint 1936.

https://cas2.umkc.edu/economics/people/facultypages/kregel/courses/econ645/winter2011/gener altheory.pdf. Retrieved on 04.04.2018.

KLEIS, M.; MOESSINGER, M.D. (2016) The Long-Run Effect of Fiscal Consolidation on Economic Growth: Evidence From Quantitative Case Studies, Discussion Paper. 2016, No. 16-047, Mannheim: ZEW.

KRUGMAN, P.R. (2015) St. Augustine and Secular Stagnation, https://krugman.blogs.nytimes.com/2015/03/16/st-augustine-and-secular-stagnation/ Retrieved on 04.04.2018.

LIPSKY, J. (2011), Fiscal Policy and Structural Fiscal Challenges, remarks by John Lipsky at the China Development Forum, https://www.imf.org/en/News/Articles/2015/09/28/04/53/sp032011, Retrieved on 04.04.2018.

LUBIŃSKI, M. (2010) Polityka fiskalna wobec kryzysu finansowego. Próba oceny. Gospodarka Narodowa. 2010, No. 9 (229), p. 1-23.

MARINAS, M.C. (2010) The Effectiveness of Fiscal Policy in Combating Economic Crisis. An Analysis Based On The Economic Literature. Theoretical and Applied Economics. 2010, Vol. XVII, No. 11, p. 63-78.

MELLONI, N. The Political Economy of Post-Crisis Economic Policies, http://www.progressiveeconomy.eu/content/political-economy-post-crisis-economic-policies-0 Retrieved on 05.04.2018.

PHELPS, E.S. (1972) Inflation Policy and Unemployment Theory. London: MacMillan, 1972.

Public Finances in EMU, European Economy. 2009, No. 5, http://ec.europa.eu/economy_finance/publications/pages/publication15390_en.pdf. Retrieved on 16.04.2018.

QAZIZADA, W., STOCKHAMMER, E. (2014) Government Spending Multipliers in Contraction and Expansion. Economic Discussion Papers. 2014, No. 2.

REINHART, C.M.; ROGOFF, K.S. (2010) Growth in a Time of Debt. NBER Working Paper. 2010, No. 15639. Issued in January 2010, Revised in December 2011.

SPILIMBERGO A., SYMANSKY S., BLANCHARD C. and COTTARELLI C., Fiscal Policy for the Crisis, SPN/08/01, https://www.imf.org/en/Publications/Policy-Papers/lssues/2016/12/31/Fiscal-Policyfor-the-Crisis-PP4307. Retrieved on 04.04.2018.

SZYMAŃSKA A. (2014) Efekt polityki fiskalnej w warunkach niskich stóp procentowych - przegląd literatury. Studia Prawno-Ekonomiczne. 2014, t. XCIII, p. 331-349.

ZIÓŁKOWSKA W. (2016) Wybrane aspekty konsolidacji fiskalnej w sektorze general government. Finanse, Rynki Finansowe, Ubezpieczenia. 2016, No. 6/2016 (84), p. 5-16, DOI:10.18276/frfu.2016.6.84/2-01. 